\title{
EFEKTIFITAS PEMBERIAN BISKUIT IKAN BILIH (Mystacoleucus padangensis) TERHADAP STATUS GIZI DAN MORBIDITAS
}

\author{
“Effect of Bilih Fish (Mystacoleucus padangensis)Biscuits on \\ Nutritional Status and Morbidity” \\ *Marni Handayani, *M. Husni Thamrin \\ (*Poltekkes Kemenkes Padang)
}

\begin{abstract}
Abstrak
The problem of malnutrition in children under five years is not a new thing, but the problem is still actual. One of the alleviation program for malnurition problem is food supplementation. The biscuits are used as food supplementation in the community, is still a food manufacturer based flour and it hasn't enriched yet by exploring the potential of local food that is rich in nutrients, such as fishery products.

This research was aimed to see the effect of Bilih fish (Mystacoleucus padangensis) biscuits on nutritional status and morbidity of malnutrition children under five years in the region of Belimbing Health Centre, Padang city.

The study is an experimental research with pre-post test one group design. Preliminary research was done to get the formula Bilih fish flour biscuits by using a completely randomized design (CRD) continued by acceptance with organoleptic test. The subjects of the research were children ages 2-5 years who where WAZ-scores $\leq-2 S D$ conducted purposively. The treatmen was given 5 times a week for 3 week. Data collected by antrophometry for nutritional status, interview for morbidity and 24 hour-recall for intake energy and nutritions. Data was analyzed in the continuous stages: data analysis to obtain the best functional biscuit formulation was obtained by ANOVA test with $95 \%$ confidence level. The effect of Bilih fish biscuits on nutritional status and morbidity was analyzed by paired T-Test.

It was found that the best biscuits formula from Bilih fish was formula F1 (Addition 10 gr of Bilih Fish flour, $500 \mathrm{kkal}$ energy, 7,8 gr protein and 1,9 $\mathrm{mg}$ zinc). The average change of WAZ-scores was 0,2 SD after treatmen. There was a decline in the number of children under five suffering from diarrhea and acute respiratory infection after treatment. There was a difference of nutritional status, intake of energy and nutrients, suffering from acute respiratory infection before and after giving the biscuits from Bilih fish flour. There was no difference in suffering from diarrhea before and after treatmen. Giving the biscuits from bilih fish flour can increase WAZ-score.

Further research conducted need to look at the acceptability and the efficacy of Bilih fish flour usage in the food processing techniques to improve the value of the food nutrition.
\end{abstract}

Keywords : bilih fish biscuits, nutritional status, morbidity, malnutrition children under five years 


\section{Pendahuluan}

Masalah gizi kurang pada balita bukanlah merupakan hal yang baru, namun masalah ini tetap aktual. Dicerminkan dengan adanya peningkatan prevalensi KEP di daerah kantong kemiskinan, kondisi ini diperparah dengan adanya bencana alam seperti gempa ataupun banjir. Secara nasional sudah terjadi penurunan prevalensi status gizi buruk-kurang pada balita dari 18,4 \% tahun 2007 menjadi $17,9 \%$ tahun 2010, tetapi pada prevalensi gizi kurang tidak terjadi penurunan atau tetap 13,0 persen (Balitbangkes, 2010).

Laporan Riskesdas (Depkes 2008) prevalensi gizi buruk di kota Padang yaitu sebesar $3,1 \%$ dan gizi kurang sebesar 12,2\%. Laporan Pemantauan Status Gizi Dinas Kesehatan Kota Padang pada tahun 2012 menunjukkan perbaikan status gizi balita melampaui target pembangunan jangka menengah (20\%) yaitu gizi buruk 1,94\% dan gizi kurang 12,58 \%, namun masih belum merata. Hal ini terlihat dari prevalensi gizi kurang (BB/U) sangat tinggi yaitu di 2 wilayah kerja Puskesmas Ambacang sebesar 25,59\% dan Puskesmas Belimbing sebesar 26,71\% (Dinkes Kota Padang, 2012).
Penelitian terdahulu menunjukkan penyebab gizi kurang berkaitan dengan kekurangan zat gizi makro yaitu protein dan energi, tetapi penelitian terbaru lebih terkonsentrasi pada zat gizi mikro yaitu defisiensi zink. Defisiensi zink selama masa anak-anak sangat berbahaya karena mempengaruhi nafsu makan dan dapat mengganggu pertumbuhan anak, meningkatkan resiko penyakit infeksi seperti diare serta infeksi saluran nafas (Brown, et al., 2007; Golden, 2009).

Defisiensi zink pada bayi dan anak berkaitan dengan MP-ASI yang tidak mengandung zink dalam jumlah yang cukup (Abrams, 2011), maka suplementasi zat gizi seperti zink pada anak-anak akan sangat bermanfaat, khususnya karena secara praktis sulit untuk meningkatkan zat gizi yang adekuat dari pola makan anak yang ada selama ini (Brown, et al., 2007).

Pengadaan PMT balita selama ini masih banyak terfokus pada kandungan zat gizi konvesional saja dan belum memperhatikan potensi fungsional. Menurut Boober et al (2006) biskuit konvensional tinggi lemak dan gula diasosiasikan tidak sehat, namun dapat di modifikasi menjadi produk biskuit fungsional. Biskuit yang digunakan 
sebagai makanan tambahan di masyarakat, masih berupa makanan pabrikan yang berbasis tepung terigu dan belum banyak yang diperkaya dengan menggali potensi pangan lokal yang kaya akan gizi, seperti produk perikanan.

Ikan Bilih (Mystacoleucus padangensis) memiliki keunggulan utama dibanding ikan lain karena selain kandungan proteinnya tinggi $(56,68 \%)$, kandungan zink nya juga tinggi, yaitu 17,33 mg/100g (Yuniritha, 2011), jauh lebih tinggi dibanding kandungan zink dari hati sapi/ unggas 4,2-6,1 mg/100g dan daging sapi 2,9-4,7 mg/100 g (Hotz dan Brown, 2004). Biskuit yang diperkaya dengan tepung ikan bilih (Biskuit fungsional) merupakan salah satu solusi yang perlu dikaji efikasinya untuk menurunkan prevalensi gizi kurang balita. Selain dapat menambah asupan energi dan protein, sifat fungsional zink nya juga dapat meningkatkan nafsu makan, meningkatkan metabolisme hormon pertumbuhan dan meningkat daya tahan tubuh sehingga balita tidak mudah sakit.

\section{Metodologi Penelitian}

Jenis penelitian eksperimental, dilakukan 2 tahap yaitu penelitian awal untuk mendapatkan formula biskuit fungsional dari tepung ikan bilih, menggunakan Rancangan Acak Lengkap (RAL) dilanjutkan dengan uji daya terima secara organoleptik. Penelitian tahap II adalah penelitian untuk melihat pengaruh pemberian biskuit fungsional dari tepung ikan bilih terhadap status gizi dan morbiditas pada anak balita gizi kurang, dengan rancangan pre-post test one group design. Subjek penelitian adalah anak balita usia 2-5 tahun yang mengalami gizi kurang ( $Z$ score $B B / U \leq-2 S D$ ) di wilayah kerja Puskesmas Belimbing, Kecamatan Kuranji Kota Padang yang ditentukan secara purposive. Intervensi dilakukan 5 kali perminggu selama 3 minggu. Data berat badan (BB) anak balita diukur dengan menggunakan timbangan injak elektrik dengan ketelitian $0.1 \mathrm{~kg}$, data morbiditas dan data karakteristik keluarga dikumpulkan dengan cara wawancara menggunakan kuesioner. Data konsumsi dikumpulkan dengan cara recall 24 jam sebanyak 2 kali (1 kali sebelum dan 1 kali sesudah perlakuan). Analisa data dilakukan bertahap : Analisis data untuk mendapatkan formulasi biskuit fungsional yang terbaik dilakukan uji daya terima dengan metode hedonik, 
dianalisis dengan uji ANOVA dengan tingkat kepercayaan $95 \%$. Analisis pengaruh pemberian biskuit dari tepung ikan bilih terhadap status gizi (indeks $\mathrm{BB} / \mathrm{U})$ dan morbiditas anak balita gizi kurang dengan menggunakan uji paired T- Test.

\section{Hasil}

\section{Kadar Zat Gizi Formula dan Uji Organoleptik}

Tabel 1

Komposisi Zat Gizi Formula Biskuit Tepung Ikan Bilih

\begin{tabular}{lccc}
\hline $\begin{array}{c}\text { Energi dan } \\
\text { zat Gizi }\end{array}$ & F1 & F2 & F3 \\
\hline Energi & 500,15 & 511,17 & 519,5 \\
Protein & 7,88 & 9,28 & 10,68 \\
Lemak & 28,59 & 28,96 & 29,34 \\
Karbohidrat & 59,53 & 59,53 & 59,53 \\
Zink & 1,91 & 2,11 & 2,82 \\
\hline
\end{tabular}

Tabel 2

Rata-Rata Penerimaan Panelis Terhadap Biskuit Tepung Ikan Bilih

\begin{tabular}{lccc}
\hline Penilaian & F1 & F2 & F3 \\
\hline Rasa & 3,43 & 2,93 & 3,03 \\
Warna & 2,97 & 3,23 & 3,13 \\
Aroma & 3,13 & 2,90 & 2,73 \\
Tekstur & 3,23 & 3,3 & 2,97 \\
\hline Jumlah & 12,76 & 12,36 & 11,86 \\
\hline Rata-Rata & 3,19 & 3,09 & 2,96 \\
\hline
\end{tabular}

Berdasarkan uji hedonik terhadap biskuit tepung ikan bilih diketahui ratarata penerimaan panelis berkisar 2,963,19 dengan kriteria hedonik suka. Nilai rata-rata penerimaan panelis tertinggi adalah pada formula F1 (penambahan tepung Ikan Bilih sebanyak 10 gr).

\section{Deskripsi Subjek Penelitian}

Anak balita gizi kurang yang menjadi subjek penelitian, diperoleh dengan menggunakan data sekunder hasil penimbangan terakhir di Posyandu dan Puskesmas Belimbing. Data tersebut kemudian diolah untuk mengetahui status gizi anak balita berdasarkan indeks BB/U. Anak balita yang mempunyai nilai z score $<-2$ SD dijadikan populasi untuk kemudian ditetapkan subjek penelitian. Karena luasnya wilayah kerja puskesmas Belimbing, maka dipertimbangkan untuk memilih anak balita gizi kurang yang berada dalam satu posyandu. Dipilih tiga posyandu yang mempunyai anak balita gizi kurangnya cukup banyak, yaitu Posyandu Kampung Pinang, Tui dan Lolo. Posyandu Kampung Pinang dan Tui berada pada daerah yang berdekatan sementara Posyandu Lolo terpisah cukup jauh dari kedua posyandu lainnya. Jumlah subjek penelitian sebanyak 24 orang anak balita. Diketahui 66,7 \% ibu anak balita berumur $>35$ tahun. $91,7 \%$ ibu balita 
adalah ibu rumah tangga. Lebih dari separoh $(54,2 \%)$ ibu balita mempunyai tingkat pendidikan SMA ke atas. Sedangkan data tentang jumlah anak dalam keluarga diketahui 66,7 \% keluarga mempunyai anak $<3$ orang.

\section{Gambaran Status Gizi (nilai $\mathrm{Z}$ score BB/U) Anak Balita}

Gambaran status gizi anak balita sebelum dan sesudah perlakuan dapat dilihat pada tabel 3 .

\section{Tabel 3}

Gambaran Status Gizi Anak Balita

Sebelum dan Sesudah Perlakuan

\begin{tabular}{lcc}
\hline Status Gizi & $\begin{array}{c}\text { Z score } \\
\text { sebelum }\end{array}$ & $\begin{array}{c}\text { Z score } \\
\text { sesudah }\end{array}$ \\
\hline Mean & $-2,56$ & $-2,36$ \\
Median & $-2,41$ & $-2,21$ \\
Std. Deviation & 0,57 & 0,55 \\
\hline Jumlah & 24 & 24 \\
\hline
\end{tabular}

\section{Morbiditas (Diare dan ISPA) pada} Anak Balita

Kejadian penyakit diare dan ISPA

yang dialami oleh anak balita sebelum dan sesudah perlakuan dapat dilihat pada tabel 4 dan 5

Tabel 4

Kejadian penyakit Diare Anak Balita Sebelum dan Sesudah Perlakuan

\begin{tabular}{lcccc}
\hline \multirow{2}{*}{ Diare } & \multicolumn{2}{c}{ Sebelum } & \multicolumn{2}{c}{ Sesudah } \\
\cline { 2 - 5 } & $\mathrm{N}$ & $\%$ & $\mathrm{~N}$ & $\%$ \\
\hline Ya & 7 & 29,2 & 5 & 20,8 \\
Tidak & 17 & 70,8 & 19 & 79,2 \\
\hline Jumlah & 24 & 100 & 24 & 100,0 \\
\hline
\end{tabular}

Tabel 5

Kejadian Penyakit ISPA Anak Balita Sebelum dan Sesudah Perlakuan

\begin{tabular}{lcccc}
\hline \multirow{2}{*}{ ISPA } & \multicolumn{2}{c}{ Sebelum } & \multicolumn{2}{c}{ Sesudah } \\
\cline { 2 - 5 } & $\mathrm{N}$ & $\%$ & $\mathrm{~N}$ & $\%$ \\
\hline Ya & 15 & 62,5 & 6 & 25,0 \\
Tidak & 9 & 37,5 & 18 & 75,0 \\
\hline Jumlah & 24 & 100 & 24 & 100,0 \\
\hline
\end{tabular}

\section{Gambaran Asupan Energi dan Zat Gizi pada Anak Balita}

Asupan energi, protein, lemak, karbohidrat dan zink anak balita pada tabel 6.

Tabel 6

Asupan Energi dan Zat Gizi Anak Balita Sebelum dan sesudah Perlakuan

\begin{tabular}{|c|c|c|c|c|c|}
\hline Asupan & Energi & $\mathrm{P}$ & $\mathrm{L}$ & $\mathrm{KH}$ & Zink \\
\hline \multicolumn{6}{|l|}{ Mean } \\
\hline Sebelum & $845,0^{*}$ & $28,7^{*}$ & $33,0^{*}$ & $109,1 *$ & $2,8^{*}$ \\
\hline Sesudah & 1102,8 & 36,25 & 41,04 & 146,14 & 5,1 \\
\hline \multicolumn{6}{|l|}{ Median } \\
\hline Sebelum & 914,2 & 29,0 & 31,2 & 116,2 & 2,8 \\
\hline Sesudah & 1041,8 & 36,95 & 34,9 & 134,3 & 4,6 \\
\hline \multicolumn{6}{|c|}{ S.Deviation } \\
\hline Sebelum & 225,47 & 10,38 & 13,62 & 37,0 & 0,9 \\
\hline Sesudah & 354,67 & 14,36 & 17,66 & 49,89 & 1,99 \\
\hline \multicolumn{6}{|l|}{ Min } \\
\hline Sebelum & 207,8 & 3,7 & 6,4 & 33,4 & 0,5 \\
\hline Sesudah & 335,8 & 8,1 & 19,0 & 32,9 & 0,8 \\
\hline \multicolumn{6}{|l|}{ Max } \\
\hline Sebelum & 1159,4 & 48,2 & 60,9 & 195,2 & 4,7 \\
\hline Sesudah & 1869,9 & 66,2 & 86,5 & 259,5 & 8,2 \\
\hline Jumlah & 24 & 24 & 24 & 24 & 24 \\
\hline
\end{tabular}




\section{Pengaruh Pemberian Biskuit Fungsional Tepung Ikan Bilih Terhadap Status Gizi dan Morbiditas Anak Balita.}

Pengaruh pemberian biskuit fungsional tepung ikan bilih terhadap status gizi dan kejadian penyakit diare serta ISPA pada anak balita dapat dilihat pada tabel 7 .

Tabel 7

Pengaruh Pemberian Biskuit Tepung Ikan Bilih Terhadap Status Gizi dan Morbiditas (Diare dan ISPA)

Pd Anak Balita Sebelum dan Sesudah

\begin{tabular}{lccccc}
\multicolumn{5}{c}{ Perlakuan } \\
\hline Variabel & Mean & SD & SE & $\begin{array}{c}\text { P } \\
\text { Value }\end{array}$ & N \\
& & & & & \\
\hline St Gizi & & & & & \\
- Sblm & $-2,56$ & 0,57 & 0,11 & 0,000 & 24 \\
- Ssdh & $-2,36$ & 0,55 & 0,11 & & \\
& & & & & \\
Diare & & & & & \\
- Sblm & 0,29 & 0,46 & 0,09 & 0,426 & 24 \\
- Ssdh & 0,21 & 0,41 & 0,85 & & \\
& & & & & \\
ISPA & & & & & \\
- Sblm & 0,62 & 0,49 & 0,10 & 0,001 & 24 \\
- Ssdh & 0,25 & 0,44 & 0,9 & &
\end{tabular}

\section{Pembahasan}

Formula Terbaik Biskuit Tepung Ikan Bilih.

Dilihat dari segi kandungan gizi biskuit tepung ikan bilih formula F1 diketahui kandungan energi 500,15 Kkal, protein 7,88 gram, lemak 28,59 gram, karbohidrat 59,53 gram dan zink 2,76 mg. Berdasarkan angka kecukupan gizi
Secara keseluruhan tidak terdapat perbedaan yang mencolok antara ketiga formula, tetapi berdasarkan uji hedonik terhadap biskuit tepung ikan bilih diketahui nilai rata-rata penerimaan panelis tertinggi adalah pada formula $\mathrm{F} 1$ (penambahan tepung Ikan Bilih sebanyak 10 gram) yaitu 3,19, pada skala hedonik suka. Panelis menilai suka terhadap rasa, tekstur dan aroma formula biskuit F1, sementara dari segi warna sedikit kurang disukai. Hal ini bisa diperbaiki dengan pemberian garnis pada permukaan biskuit. Berdasarkan tanggapan panelis terhadap tekstur biskuit yang dibuat yaitu cukup keras sehingga perlu dibuat lebih lembut lagi karena yang mengkonsumsi adalah anak balita.

Dari segi aroma dan rasa biskuit tepung ikan bilih ini masih berbau dan terasa ikannya. Semakin ditingkatkan penambahan tepung ikan bilih maka semakin kuat aroma dan rasa ikan pada biskuit yang dibuat, hal ini mempengaruhi daya terima panelis.

(AKG) tahun 2012, maka zat gizi sehari untuk anak usia 1-3 tahun adalah : energi $1125 \mathrm{Kkal}$, protein 26 gram, lemak 44 gram, karbohidrat 155 gram, zink 4 mg, dll. Untuk anak usia 4-6 tahun : energi $1600 \mathrm{Kkal}$, protein 35 gram, lemak 62 
ram, karbohidrat 220 gram, zink 5 mg, dll.

Pemberian biskuit tepung ikan bilih kepada anak balita sudah bisa memberikan tambahan asupan energi dan zat gizi sekitar 30-50\% dari angka kecukupan gizinya. Terutama juga membantu dalam pemenuhan asupan zink pada anak balita.

Defisiensi zink selama masa anak-anak sangat berbahaya karena mempengaruhi nafsu makan dan dapat mengganggu pertumbuhan anak, meningkatkan risiko penyakit infeksi seperti diare serta infeksi saluran nafas (Brown, et al, 2007, Golden, 2009 dan Ninh, et al., 1996). Defisiensi zink pada bayi dan anak berkaitan dengan MP-ASI yang tidak mengandung zink dalam jumlah yang cukup (Abrams,2011), maka suplementasi zat gizi seperti zink pada anak-anak akan sangat bermanfaat, khususnya karena secara praktis sulit untuk meningkatkan zat gizi yang adekuat dari pola makan anak yang ada selama ini (Brown, et al., 2007).

\section{Pengaruh Pemberian Biskuit Fungsional Tepung Ikan bilih Terhadap Asupan Energi dan Zat Gizi Anak Balita.}

Hasil penelitian diketahui ada perbedaan yang bermakna rata-rata asupan energi dan zat gizi anak balita sebelum dan sesudah perlakuan, ini berarti ada pengaruh pemberian biskuit tepung ikan bilih terhadap asupan energi dan zat gizi anak balita.

Berdasarkan hasil recall makanan yang dikonsumsi oleh anak balita sebelum perlakuan, menunjukkan bahwa $100 \%$ rerata asupan energi masih kurang dari kebutuhan berdasarkan angka kebutuhan zat gizi yang dianjurkan (AKG) untuk anak balita tahun 2012. Demikian juga untuk asupan karbohidrat dan zink, semua anak balita asupannya masih kurang dari AKG.

Sedikit berbeda untuk asupan Protein dan lemak. Hasil recall untuk asupan protein anak balita menunjukkan sebanyak 33,3 \% anak balita asupan proteinnya telah memenuhi AKG. Sementara untuk asupan lemak hanya 8,3 $\%$ anak balita yang asupan lemaknya cukup atau memenuhi AKG.

Dibandingkan dengan hasil recall asupan energi dan zat gizi setelah diberikan perlakuan (pemberian biskuit tepung ikan bilih) maka terdapat perubahan terhadap asupan anak balita. Secara keseluruhan terjadi peningkatan asupan energi dan zat gizi pada anak balita. Untuk asupan energi, hasil recall diakhir penelitian diketahui $20,8 \%$ anak balita asupan energinya sudah memenuhi 
AKG. 62,5 \% anak balita asupan proteinnya sudah memenuhi AKG. Distribusi anak balita yang asupan proteinnya cukup ini, meningkat 2 kali lipat dibanding asupan protein sebelum perlakuan.

Asupan lemak dan karbohidrat anak balita setelah diberi biskuit tepung ikan bilih menunjukkan juga terjadi peningkatan. Sebanyak 20,8 \% anak balita asupan lemak dan karbohidratnya telah memenuhi AKG. Sementara untuk asupan zink, 58,3\% anak balita asupan zinknya sudah memenuhi AKG. Proporsi ini jauh meningkat karena pada awal penelitian, semua anak balita asupan zinknya dibawah AKG.

Hasil penelitian ini sejalan dengan hasil penelitian Kurnia, P dkk (2010) yang meneliti efek fortifikasi fe dan zn pada biskuit yang diolah dari kombinasi tempe dan bekatul untuk meningkatkan kadar albumin anak balita gizi kurang dan anemia, dimana diketahui ada peningkatan asupan energi dan protein setelah anak diberi biskuit tempe yang difortifikasi dengan zn dan fe tiga kali perminggu selama 12 minggu.

Pada kondisi kekurangan zat gizi, absorbsi zat gizi akan lebih efisien sehingga utilisasi zat gizi di dalam tubuh lebih optimal. Disisi lain, Zn mampu memperbaiki imunitas tubuh. Zn sendiri berfungsi memperbaiki indra pengecap, sehingga memperbaiki nafsu makan dan mempengaruhi terhadap jumlah asupan.

\section{Pengaruh Pemberian Biskuit Tepung}

\section{Ikan bilih Terhadap Morbidita}

(Diare dan ISPA) Anak Balita.

Hasil uji statistik di dapatkan tidak ada perbedaan yang bermakna antara kejadian diare pada anak balita sebelum dan sesudah pemberian biskuit tepung ikan bilih. Tetapi terdapat perbedaan yang bermakna antara kejadian ISPA pada anak balita sebelum dan sesudah pemberian biskuit tepung ikan bilih.

Pada awal penelitian diketahui 29,2 \% anak balita mengalami diare dan $62,5 \%$ anak balita mengalami ISPA. Sementara hasil wawancara tentang kejadian penyakit diare dan ISPA selama waktu intervensi diketahui $20,8 \%$ anak masih mengalami diare dan $25 \%$ mengalami ISPA. Jika dilihat hasil di atas, sudah terjadi penurunan kejadian penyakit infeksi tersebut walaupun secara statistik pada kasus diare tidak terdapat perbedaan yang bermakna.

Dibeberapa negara berkembang telah dilakukan penelitian tentang suplementasi zn dan fe. Beberapa penelitian tersebut menunjukkan hasil 
bahwa suplementasi zink dapat menurunkan penyakit infeksi (diare dan batuk) dan meningkatkan pertumbuhan anak. Suatu penelitian yang telah dilakukan pada bayi yang berat badan lahirnya rendah di Brazil menunjukkan bahwa suplementasi zink $5 \mathrm{mg}$ pada 11 bayi dapat menurunkan prevalensi diare sebesar $28 \%$ dan dapat menurunkan prevalensi batuk sebesar 33\% (Lira, et all., 1998 dalam Nasution. E, 2004).

Sistim imun dalam tubuh dipengaruhi oleh tingkat adanya zink dalam tubuh. Kekurangan zink yang parah melemahkan fugsi imun. Zink diperlukan bagi pengembangan dan pengaktifan T-Limposit, yaitu sejenis sel darah putih yang berfungsi untuk memerangi penyakit. Disaat suplemen zink diberikan pada individu yang memiliki zink rendah, jumlah sel TLimposit dalam darah meningkat dan kemampuan sel limposit dalam memerangi infeksi meningkat.

Studi menunjukkan anak-anak yang miskin dan kekurangan nutrisi di India,Afrika, Amerika selatan, dan Asia tenggara bisa sembuh lebih dengan cepat dari penyakit diare setelah minum suplemen zink. Jumlah zink yang diberikan pada studi tersebut berkisar 4 mg perhari hingga $40 \mathrm{mg}$ per hari dan diberikan dalam bentuk zink yang bervariasi(zink asetat, zink asetat, zink glukonat atau zink sulfat).

Mekanisme interaksi antara infeksi dan malnutrisi atau KEP pada umumnya disertai dengan penekanan sistem kekebalan tubuh. Keadaan tersebut dapat digambarkan sebagai berikut: (1) pada malnutrisi terjadi penurunan sintesis protein, penurunan regenerasi sel, dan terjadi gangguan metabolisme, (2) pada infeksi terjadi proses peradangan, demam, dan katabolisme naik disertai peningkatan nitrogen urin, dan (3) pada penekanan imunitas terjadi sistem kekebalan sel yang menurun, respon antibodi tidak memadai, disertai imunitas mukosa menurun dan gangguan fungsi fagosit. Mekanisme inilah yang menjelaskan mengapa anak yang menderita malnutrisi sering terserang penyakit infeksi.

Selain itu konsumsi makanan yang kurang dari kebutuhan akan mempengaruhi status gizi yang selanjutnya berdampak langsung pada penurunan status imun atau kekebalan tubuh seseorang. Kondisi ini akan memperburuk status kesehatan, sehingga anak mudah terserang beberapa penyakit yang bersumber dari lingkungan yang buruk, seperti penyakit infeksi. 
Pengaruh Pemberian Biskuit

Tepung Ikan BilihTerhadap Status Gizi Anak Balita.

Hasil uji statistik di dapatkan ada perbedaan yang bermakna antara status gizi (nilai $\mathrm{Z}$ score $\mathrm{BB} / \mathrm{U}$ ) pada anak balita sebelum dan sesudah pemberian biskuit tepung ikan bilih. Diketahui ratarata $\mathrm{z}$ score $\mathrm{BB} / \mathrm{U}$ anak balita adalah -2 , 56 sebelum diberi perlakuan dan $-2,36$ setelah diberi perlakuan.

Suatu meta analisis dari 25 penelitian tentang pengaruh suplementasi zink pada pertumbuhan anak yang dilkukan oleh Brown (1998), menunjukkan bahwa pemberian suplementasi zink secara statistik bermakna memberikan efek yang lebih baik terhadap pertumbuhan secara linier dan pertambahan berat badan anak. Demikian juga temuan pada penelitian Handayani (2010) dimana terdapat pengaruh pemberian suplementasi zink, kalsium, fosfor dan vitamin D terhadap pertumbuhan anak SD yang stunted.

Hasil beberapa penelitian yang telah dilakukan sebelumnya, bahwa pemberian makanan tambahan dalam waktu yang relatif lama akan memperbaiki berat badan. Hal ini dapat dijelaskan bahwa asupan zat gizi secara langsung akan mempengaruhi status gizi seseorang, artinya jika jumlah asupan zat gizi yang berasal dari makanan yang dikonsumsi meningkat, maka status gizi pun akan meningkat pula. Disisi lain, bertambahnya usia secara fisiologis yang normal juga mempengaruhi peningkatan konsumsi makanan, sehingga jumlah asupan zat gizi juga bertambah. Pemberian biskuit dari tepung ikan bilih pada anak gizi kurang dapat meningkatkan pertumbuhan atau status gizi.

\section{Simpulan}

Ada pengaruh pemberian biskuit dari tepung Ikan Bilih terhadap status gizi dan morbiditas anak balita gizi kurang

\section{Saran}

Perlu dipertimbangkan pemberian biskuit tepung ikan bilih untuk menjadi salah satu jenis makanan dalam program Pemberian Makanan Tambahan (PMT) pada Balita. Perlu dilakukan penelitian lanjutan daya terima dan efikasi penggunaan tepung ikan bilih dalam berbagai teknik pengolahan pangan sehingga dapat ditingkatkan nilai gizi pada makanan tersebut.

\section{Daftar Pustaka}

Abrams, S. A., Motil, K. J. \& Hoppin, A. G. 2011 Zinc deficiency and supplementation in children and 
adolescents.

Available:

http://www.uptodate.com/conten

ts/ zinc-deficiency-and-

supplementation-in-children-

and-adolescents. Accessed: [18 Maret 2013].

Balibangkes, Depkes. 2008. Laporan Nasional Riset Kesehatan Dasar 2007. Jakarta.

Balitbangkes, Kemenkes, 2010. Laporan Riset Kesehatan Dasar 2010. Jakarta.

Boober WJ, Beker JS, Davies B, 2006. Development of healthy biskuit: an alternative approach to biskuit manufacture. Nutrition Journal 2006

Brown, K. H., de Roman, D. L. p., Arsenault, J. E., Peerson, J. M. \& Penny, M. E, 2007. Comparison of the effects of zinc delivered in a fortified food or a liquid supplement on the growth, morbidity, and plasma zinc concentrations of young Peruvian children. Am J Clin Nutr 85:538-47

Dinas Kesehatan, 2008. Profil Kesehatan Kota Padang.

Dinas Kesehatan Kota Padang, 2012. Pemantauan Status Gizi Anak Balita Kota Padang

Handayani, M. 2010. Pengaruh Pemberian Suplementasi Zink, Kalsium, Fosfor dan Vitamin D terhadap Pertumbuhan Anak Sekolah Dasar Yang Pendek Di Kota Payakumbuh. Jurnal Sehat Mandiri. Poltekkes Kemenkes Padang
Hotz, C. \& Brown, K. H. 2004. Assessment of the Risk of Zinc Deficiency in Populations and Options for and Options for Its Control. Food and Nutrition Bulletin. USA: United Nations University Press

Yuniritha, 2011. Analisis komposisi zat Gizi Makro dan Mikro Ikan Bilih 